Original Research Paper

\title{
Productive and Economic Performances of Magelang Duck Fed on Fermented Kariba Weed
}

\author{
Agus Setiadi, Siswanto Imam Santoso, Edjeng Suprijatna, Teysar Adi Sarjana and Joko Mariyono \\ Department of Agriculture, Faculty of Animal and Agricultural Sciences, Universities Diponegoro, Semarang, Indonesia
}

\author{
Article history \\ Received: 24-08-2021 \\ Revised: 03-10-2021 \\ Accepted: 05-10-2021 \\ Corresponding Author: \\ Agus Setiadi \\ Universitas Diponegoro, \\ Semarang, Indonesia \\ Email: agussetiadi@lecturer.undip.ac.id
}

\begin{abstract}
The duck farming business faces the high feeding costs problem. Kariba Weed $(\mathrm{KW})$ is an alternative feed that has been widely used as a source of ducks' feeding materials. However, a problem exists because KW contains high crude fibre. Fermented $\mathrm{KW}$ that contains microbes will reduce the crude fibre content, leading to a good quality of duck meat. This study aimed to perform technical and economic analysis about the Fermented Kariba Weed (FKW) effect on the male Magelang duck's growth. The research was conducted in Faculty of Animal and Agricultural Sciences, Diponegoro University, Indonesia. The research used 240 male Magelang ducks with 741.61 $\pm 251.57 \mathrm{~g}$ body weight. Research used Randomized Block Design (RBD) with five treatments and six replications. Each experimental unit consisted of eight ducks. The treatments included F0: Ration using nonKW, F1: Rations containing KW fermented with Aspergillus niger (AFKW), F2: Rations containing KW fermented with Rhizopus (RFKW), F3: Rations containing KW fermented with Trichoderma sp (TFKW) and F4: Rations containing KW fermented with Termite digestive tract enzymes (TDTFKW). Research lasted 6 weeks. This research's parameters were feed consumption, daily weight gain, Feed Conversion Ratio (FCR), mortality, final weight gain and economic feasibility indicators. The results showed a significant difference in duck feed and showed the best effect in the AFKW treatment. The AFKW gave the best results. Feed consumption was significantly different $(p=0.002)$ among the other treatments. The results showed that giving AFKW in duck feed could reduce cholesterol and triglyceride levels. The AFKW adoption was economically feasible when the farmer raised 2,000 ducks. The economic feasibility analysis showed an investment value requirement of Indonesian Rupiah (IDR) 89,000,000, with a net present value in IDR 148,000,000, with a payback period of 21 months, a benefit-cost ratio of 1.3, Internal Rate of Return (IRR) was 51.06 and price sensitivity analysis was $23 \%$. The AFKW use on farmers' scale could lower cholesterol and triglycerides levels in duck meat and also provided the highest income.
\end{abstract}

Keywords: Fermented Kariba Weed (FKW), Economic Analysis, Magelang Duck, Technical Parameters

\section{Introduction}

The demand for duck meat in Indonesia is increasing yearly. However, consumer concerns about duck meat's high cholesterol and triglyceride content cause consumers to become hesitant to consume the meat in large quantities. In response to this circumstance, it is vital to increase duck farming productivity while lowering its cholesterol and triglyceride level.

Feeding materials contribute the majority of duck production costs. In Indonesia, the majority of corn and soybean meal must be imported from another country. As a result of this circumstance, the availability and price of poultry feed often fluctuate. The Kariba Weed (KW) is a type of alternative feed ingredient frequently used in poultry feed nowadays (Mukherjee et al., 2010; Santoso et al., 2017). The KW is an aquatic plant commonly found in Indonesian lakes, dams and slow-flowing rivers. It has the potential to be a low-cost local component with a vitamin C content of $3.20 \mathrm{mg} / 30 \mathrm{~g}, 111.24 \mathrm{mg} / \mathrm{kg} \beta$-carotene, $15.9 \%$ crude protein, $17.21 \%$ crude fibre, $2,200 \mathrm{kcal} / \mathrm{kg}$ metabolic energy and hemicellulose (Anderson et al., 2011). 
Yet, one of the disadvantages of $\mathrm{KW}$ is that it is rich in fibre. To increase feed quality, an attempt to minimize fibre content is therefore required.

Fermentation is a simple way for improving the nutritional value of feed materials, particularly to enhance protein content while lowering crude fibre level (Sugiharto and Ranjitkar, 2019). With improved nutritional value, alternative feed ingredients in poultry rations are expected to reduce feed costs so that economic efficiency will increase. Various microorganisms, principally bacteria and fungi can be used to ferment the unconventional feed materials. Fungal fermentation appears to be an appropriate approach for lowering fibre content (Sugiharto, 2019). On this background, fermentation was conducted on KW to reduce its fibre content particularly. This study aimed to evaluate how employing Fermented Kariba Weed (FKW) affected the growth performance, cholesterol and triglyceride levels in duck meat and to figure out how many Magelang ducks need be raised with FKW-based diets to run a profitable business.

\section{Materials and Methods}

The Magelang duck inbred was chosen as the study's subject. Magelang duck is a native Indonesian inbred duck species that produce a lot of eggs and meat. The regencies of Magelang, Temanggung and Wonosobo and the neighbouring territories are home to this inbred. The Magelang duck has the potential to become a profitable venture. At the Faculty of Animal and Agricultural Sciences, Universitas Diponegoro, an experimental investigation was carried out. The study used 240 male Magelang ducks with a bodyweight of $741.61 \pm 251.57 \mathrm{~g}$ procured from the Central Java Province's Ducks Breeding Unit.

The cage model in this experiment was a flock. Equipment used includes up to 30piece feed and drinking containers, digital scales with a capacity of $5 \mathrm{~kg}$ and an accuracy level of $0.1 \mathrm{~g}$ for weighing feed, hanging scales with a total of $50 \mathrm{~kg}$ and an accuracy level of $0.1 \mathrm{~g}$ for weighing ducks and cage spray. This study adopted a Randomized Block Design (RBD) as an experimental model of analysis. There were five treatments and six replications. The treatments included F0: Ration using nonfermented KW, F1: Rations containing KW fermented using Aspergillus niger, F2: Rations containing KW fermented using Rhizopus sp., F3: Rations containing KW fermented using Trichoderma sp. and F4: Rations containing KW fermented using termite enzymes. Bodyweight become a grouping factor. Each treatment consisted of 8 ducks. The feed consumption ratio also can be seen in Table 1 .

This experiment was conducted at the Faculty of Animal and Agricultural Sciences, Universitas Diponegoro, Semarang, Indonesia. The KW was taken from Rawa Pening Lake, Semarang Regency, Central Java. The KW was harvested from Rawa Pening lake. It was sundried for three days and ground into a powder form. The cost of producing $120 \mathrm{~kg}$ of $\mathrm{KW}$ as feed material in a single batch was Indonesian Rupiah (IDR) 300,000. The cost consisted of labour cost and transportation cost. The cost of making $\mathrm{KW}$ powder was estimated to be IDR 2,500 per $\mathrm{kg}$. F0 had a price ratio of IDR $5576 / \mathrm{kg}$, F1 IDR $5,778 / \mathrm{kg}$, F2 IDR $5,890 / \mathrm{kg}, \mathrm{F} 35,664 / \mathrm{kg}$ and F4 IDR 5,840/kg.

\section{Meat Cholesterol and Triglyceride Content Determination}

This study used a non-saponifiable fraction with threetime extraction using $10 \mathrm{~mL}$ hexane. An amount of $5 \mathrm{~mL}$ of water was added and the samples were cooled. The modified saponification process was used for measuring cholesterol content. Each sample, approximately $2 \mathrm{~g}$, was saponified with $4 \mathrm{~mL}$ potassium hydroxide $(50 \%)$ and $6 \mathrm{~mL}$ ethanol (95\%), absolute, heated at $40^{\circ} \mathrm{C}$ to complete solubilisation and then heated at $60^{\circ} \mathrm{C}$ for 10 minutes. The extract dilution of $0.2 \mathrm{~mL}$ isopropyl alcohol was analyzed with an enzymatic kit (Merck® Diagnostica, Darmstadt, Germany). Extracts of Aliquots of hexane $(3 \mathrm{~mL})$ were dried under a flow of nitrogen. Samples were analyzed by enzymatic methods after saponification (Dwiloka et al., 2015).

Data Analysis

\section{Feed Intake}

Following Rathod et al. (2019), feed intake was measured by weighing the feed given minus the daily feed not consumed during treatment (g/week).

$$
\text { Feed Intake }=\frac{(\text { feed given }- \text { leftover })}{\text { week } .}
$$

\section{Feed Conversion Ratio (FCR)}

FCR was measured by dividing the amount consumed by body weight gain (Santoso et al., 2017).

$$
\text { Feed Conversion Ratio }=\frac{\text { amount of feed eaten }}{\text { weight gain }}
$$

\section{Feed Costs}

Feed costs were calculated from the duration of the treatments for 1 to 6 weeks. The feed cost was calculated based on the price of a feed multiplied by the daily intake then expressed in IDR/head/day (Chander et al., 2017). Meanwhile, the feed price (IDR/kg) was measured by multiplying the price of each ingredient used in the study, then multiplying the amount of feed composition. The $\mathrm{KW}$ (IDR/kg) price was calculated from the wage divided by the number of working days (which was produced by $\mathrm{KW}$ in a wet form then converted into dry matter) plus 
transportation and milling costs. The feed costs were added with fermenting agents, namely Aspergillus niger, Trichoderma, Rizhopus and termite digestive tract bacteria.

\section{Income Over Feed Cost (IOFC)}

Income minus feed and is expressed in IDR/head (Rawat et al., 2018).

$$
\begin{aligned}
& \text { IOFC }=(B B \times \text { chicken price } / \mathrm{kg} / \text { live duck }) \\
& -\left(\sum \times \text { feed int ake of feed cost } / \mathrm{kg}\right)
\end{aligned}
$$

\section{Economic Performance}

Economic performance was calculated by dividing IOFC by feed costs. Other costs were assumed to be fixed. The economic performance of using FKW as feed for male Magelang ducks was measured by calculating feed price income, feed cost and IOFC. A feasibility study was calculated to determine the business potential of Magelang ducks using FKW as feed. Investment analysis was carried out with the assumption that each duck farmer manages 2,000 male Magelang ducks. Following, Paguia et al. (2014) and Reyes et al. (2018), economic feasibility analysis used Payback Period (PP), Net Present Value (NPV) and Benefit-Cost Ratio (BCR), Internal Rate of Return (IRR) and feed price sensitivity analysis.

\section{Statistical Analysis}

This study applied the General Linear Model (GLM) executed using SPSS ver. 16.0. The General Linear Model (GLM) is a powerful analytical tool to compare the differences of several variables affecting continuous variables (Rutherford, 2001). The mean of each treatment was evaluated using Least Square Means (LKW) and the mean differences among treatments were analyzed using Duncan Multiple Range Test (DMRT).

\section{Results}

Table 1 shows the main findings of the analyses. There were significant differences in F0, F1, F2, F3 and F4 treatments. The final weight of the Magelang duck fed with F1 gave the best results. Duck-fed AFKW (F1) produced the best final weight. The gain of Magelang duck fed F1 gave the best results. The final body weight of ducks given AFKW was higher than ducks fed with F0, F2, F3 and F4. The FCR of Magelang duck fed with F1 gave the best results. The FCR of ducks that were given AFKW was lower than ducks fed F0, F2, F3 and F4. The difference in average duck intake between the control and FKW treatments was not statistically significant $(\mathrm{P}<0.05)$.

As shown in Table 2, the economic parameter showed that duck fed F1 gave the best result. The fermentation process of KW using Aspergillus niger performed the highest economic performance. The use of F1 (AFKW) to feed ducks will reduce feed prices. During the study period, the mortality rate of the duck was zero. The price of harvested ducks fed with F1 (AFKW) is the most expensive among duck fed other feeds.

As shown in Table 3, the economic calculation when farmers raise 2,000 heads of duck, they need 89,000,000 feed AFKW, the duck will be raised at four months and based on feasibility analysis. The economic feasibility indicators indicate that NPV was $148,000,000$, PP was 21 months, BCR was 1.3 , IRR was $51.06 \%$ and feed sensitivity analysis was $23 \%$. These conditions imply that the duck business would benefit the farmers.

As shown in Fig. 1, duck meat's cholesterol level would decrease when duck fed by FKW. Duck meat of F1 (AFKW) showed the lowest amount. The fermentation process using Aspergillus niger performed the best duck meat cholesterol.

Figure 2, the triglyceride content of duck meat was lowest in duck fed $\mathrm{T} 1$.

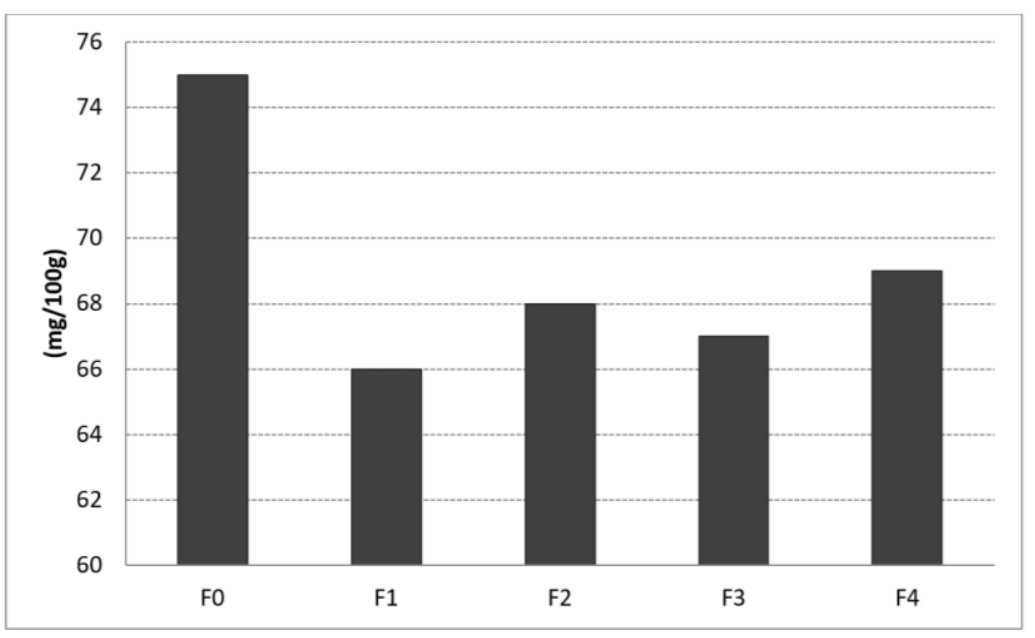

Fig. 1: Cholesterol level of duck meat fed with FKW in the diet $(\mathrm{mg} / 100 \mathrm{~g})$ 


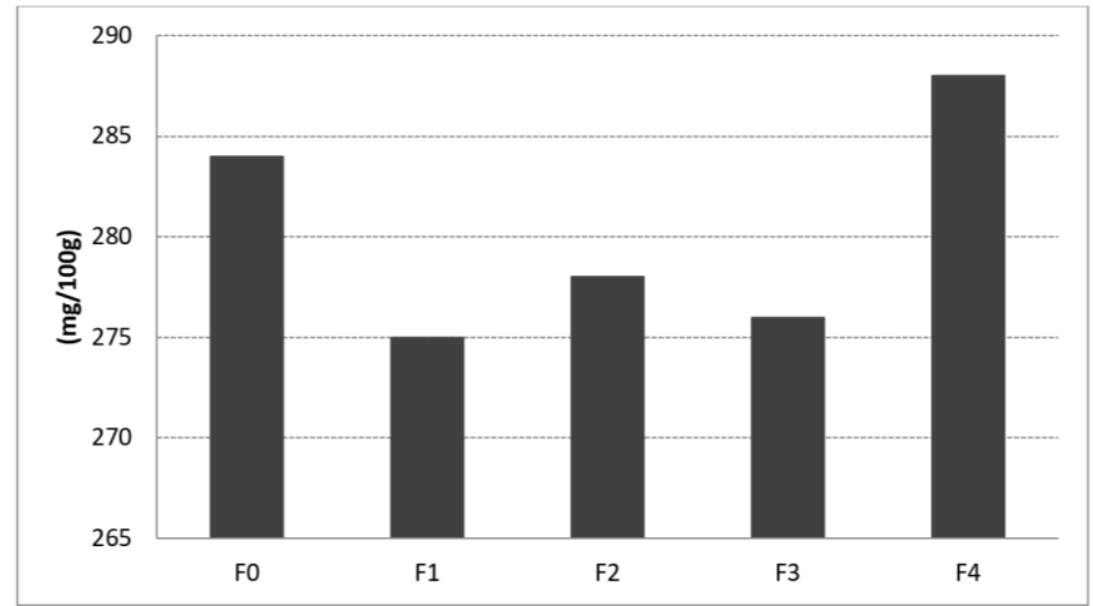

Fig. 2: Triglyceride level of duck meat fed FKW in the diet $(\mathrm{mg} / 100 \mathrm{~g})$

Table 1: Feed ingredient composition of the ration

\begin{tabular}{|c|c|c|c|c|c|}
\hline \multirow[b]{2}{*}{ Composition } & \multicolumn{5}{|c|}{ Treatments } \\
\hline & F0 & $\mathrm{F} 1$ & $\mathrm{~F} 2$ & F3 & $\mathrm{F} 4$ \\
\hline Ingredients & & $\%$ & & & \\
\hline Lysine & 0.7 & 0.7 & 0.7 & 0.9 & 0.5 \\
\hline Corn & 52.4 & 52.3 & 51.3 & 52.5 & 52.9 \\
\hline Soybean meal & 12.2 & 11.6 & 12.3 & 12.9 & 13.4 \\
\hline Rice bran & 11.5 & 12.2 & 12.5 & 11.1 & 10.5 \\
\hline KW & 15.0 & 15.0 & 15.0 & 15.0 & 15.0 \\
\hline Fish meal & 5.5 & 5.5 & 5.5 & 5.5 & 5.5 \\
\hline Coconut oil & 0.5 & 0.5 & 0.5 & 0.5 & 0.7 \\
\hline $\mathrm{CaCO}_{3}$ & 0.7 & 0.7 & 0.7 & 0.7 & 0.5 \\
\hline Premix & 0.7 & 0.8 & 0.8 & 0.5 & 0.5 \\
\hline Methionine & 0.8 & 0.7 & 0.7 & 0.4 & 0.5 \\
\hline Number & 100 & 100 & 151.10 & 100 & 100 \\
\hline \multicolumn{6}{|l|}{ Nutrition analysis } \\
\hline $\mathrm{Ca}(\%) * *$ & 1.51 & 1.85 & 1.71 & 1.49 & 1.36 \\
\hline Energy $\left(\mathrm{kcal} \mathrm{kg}^{-1}\right)$ & 2806.70 & 2806.74 & 2806.19 & 2809.84 & 2812.23 \\
\hline Crude protein $(\%) *$ & 17.22 & 17.35 & 17.45 & 17.46 & 17.32 \\
\hline Fat $(\%)^{*}$ & 5.17 & 5.03 & 4.86 & 4.62 & 4.30 \\
\hline Crude Fibre $(\%)^{*}$ & 6.99 & 7.41 & 7.78 & 7.83 & 8.59 \\
\hline Methionine $(\%) * *$ & 0.91 & 1.03 & 0.90 & 0.72 & 0.78 \\
\hline Lysine $(\%)^{* *}$ & 1.56 & 1.65 & 1.74 & 1.50 & 1.19 \\
\hline $\mathrm{P}(\%)^{* *}$ & 0.51 & 0.50 & 0.50 & 0.48 & 0.64 \\
\hline Price $\mathrm{kg}^{-1}$ & 5,576 & 5,778 & 5,890 & 5,664 & 5,840 \\
\hline
\end{tabular}

Sources: SNI (2017), F0 = non fermented KW, F1 = AFKW, F2 = RFKW, F3 = TFKW, F4 = TDTFKW, AFKW = Aspergillus niger fermented Kariba weed, F2 = RFKW = Rizopus Fermented Kariba weed, TFKW = Trichoderma Fermented Kariba weed and TDTFKW $=$ Termite digestive tract enzyme fermented kariba weed

** What about these stars

Table 2: Performance of duck fed supplemented with fermented kariba weed

\section{Treatments}

\begin{tabular}{llllll} 
Items & F0 & F1 & F2 & F3 & F4 \\
\hline Final weight $\left(\right.$ gram head $\left.^{-1}\right)$ & $1259.56 \pm 102.47^{\mathrm{a}}$ & $1306.69 \pm 82.95^{\mathrm{b}}$ & $1277.60 \pm 66.03^{\mathrm{a}}$ & $1261.25 \pm 69.65^{\mathrm{a}}$ & $1218.44 \pm 110.16^{\mathrm{c}}$ \\
Gain $\left(\right.$ gram head $\left.^{-1}\right)$ & $390.71 \pm 139.88^{\mathrm{a}}$ & $474.19 \pm 125.95^{\mathrm{b}}$ & $438.27 \pm 153.42^{\mathrm{ab}}$ & $436.77 \pm 150.61^{\mathrm{ab}}$ & $377.19 \pm 125.23^{\mathrm{ab}}$ \\
FCR & $3.51 \pm 0.19^{\mathrm{ab}}$ & $3.35 \pm 0.11^{\mathrm{a}}$ & $3.44 \pm 0.12^{\mathrm{ab}}$ & $3.49 \pm 0.11^{\text {ab }}$ & $3.62 \pm 0.24^{\mathrm{b}}$ \\
Feed Consumption $\left(\right.$ gram head $\left.^{-1}\right)$ & $660,60 \pm 18,04^{\mathrm{a}}$ & $655,80 \pm 23,29^{\mathrm{a}}$ & $658,04 \pm 19,52^{\mathrm{a}}$ & $659,13 \pm 18,36^{\mathrm{a}}$ & $658,01 \pm 20,02^{\mathrm{a}}$ \\
\hline
\end{tabular}

**Different superscripts show a real difference $(\mathrm{P} \leq 0.05)$ 
Table 3: Economic parameter magelang duck fed FKW (per 8 ducks)

\begin{tabular}{llllll}
\hline Economic parameter & F0 & F1 & F2 & F3 & F4 \\
\hline Mortality & 0 & 0 & 0 & 0 & 0 \\
Final weight (kg) & 1259.56 & 1306.69 & 1277.60 & 1261.25 & 1218.44 \\
Price/head (IDR) & 45,000 & 55,000 & 50,000 & 50,000 & 45,000 \\
Feed cost (IDR) & 147,339 & 151,568 & 155,034 & 149,332 & 153,711 \\
Income (IDR) & 360,000 & 440,000 & 440,000 & 400,000 & 360,000 \\
IOFC (DR) & 212,661 & 288,432 & 284,966 & 250,668 & 206,289 \\
\hline
\end{tabular}

Source: Data analysis

Table 4: Investment analysis of AFKW (Aspergillus niger fermented kariba weed) to Magelang duck

\begin{tabular}{ll}
\hline Items & F1 \\
\hline NPV (IDR) & $148,000,000$ \\
PP (month) & 21 \\
BCR & 1.3 \\
IRR (\%) & 51.06 \\
Feed sensitivity analysis (\%) & 23 \\
\hline
\end{tabular}

\section{Discussion}

Reduced production costs in chicken production may typically be achieved by employing alternative feeding materials that do not compete with human needs (Chander et al., 2017). Fermentation is a typical way to improve the quality of feed. In this study, duck performance was improved the most when $\mathrm{KW}$ was fermented with Aspergillus niger. In this regard, Aspergillus niger can lower the fibre content in $\mathrm{KW}$, thus allowing ducks to optimally use the feed. Note that the lower fibre content was generally attributed to the animals' increased digestibility and nutrient utilization of feed (Sugiharto and Ranjitkar, 2019). In support, Ibrahim et al. (2020) found that fermented feed can increase growth performance.

It is interesting to report in this investigation that feeding diets containing FKW resulted in lower cholesterol and triglyceride contents in duck meats. In line with this finding, Dwiloka et al. (2015) documented that incorporating $\mathrm{KW}$ in duck rations reduced cholesterol levels in meat. In term of fermentation effect, Ibrahim et al. (2021) reported that feeding fermented, dried olive pomace reduce fat and cholesterol levels in the meat of broiler chickens. The latter further suggested that the decrease in fat and cholesterol contents can be caused by fermentation products such as short-chain fatty acids that suppress hepatic fat and cholesterol synthesis. Overall, the lower cholesterol and triglyceride levels in meats could increase the preference and price of duck meat.

The increase in the ducks' selling price causes the income of farmers to increase. Raising 2,000 ducks fed AFKW will produce a viable business for duck farmers, as indicated with favorable economic indicators for NPV, PP, BCR and IRR (See Table 4). Raising 2,000 ducks will produce a feasible business for duck farmers, as indicated with favorable economic indicators of NPV, PP, BCR and IRR. Study of Santoso et al. (2016) observed a decent profit, the minimum number of ducks that must be kept is 2000 heads. Magelang 2000 heads duck business with AFKW feed requires IDR 89,000,000 investment. This investment amount will be returned 21 months after the operation. Economic analysis shows that the Magelang duck business is very profitable. This result is in line with Santoso et al. (2016) research in another poultry type; but it's higher than Dolewikou et al. (2016), which examined the dairy cattle business. The IRR value shows a $51.06 \%$ value with a $23 \%$ sensitivity value, which means that the profits from the duck business are sensitive to changes in AFKW feed prices. A feed price increase will reduce the profits obtained. Duck business is very sensitive to changes in feed prices. AFKW diet provides cheap feed for the ducks raising in Indonesia.

\section{Conclusion}

Incorporating $\mathrm{FKW}$, especially fermented with Aspergillus niger (AFKW), in duck rations provided the best growth and economic performance. The treatment also reduced cholesterol and triglyceride levels, thus increasing the price of meats. Operating a business with 2,000 heads of Magelang duck is highly recommended since the business will increase the income of the duck farmers.

\section{Acknowledgment}

The authors would like to thank the Directorate of Research and Community Service, Ministry of Research, Technology and Higher Education of the Republic of Indonesia for funding this research.

\section{Author's Contributions}

Agus Setiadi: Problem formulation, data analysis and interpretation, manuscript preparation.

Siswanto Imam Santoso: Policy and problem formulations.

Edjeng Suprijatna: Discussion on feeding technology.

Teysar Adi Sarjana: Discussion on feed materials and nutrition.

Joko Mariyono: Problem formulation, interpretation of data analysis and policy implications. 


\section{Ethical Approval}

The animal ethics committee of the Faculty of Animal and Agricultural Sciences, Diponegoro University, approved the experiment (No. 3122/UN.7/V/2019, 28 May 2019).

\section{References}

Anderson, K. E., Lowman, Z., Stomp, A. M., \& Chang, J. (2011). Duckweed as a feed ingredient in laying hen diets and its effect on egg production and composition. Int J Poult Sci, 10(1), 4-7. doi.org/10.3923/ijps.2011.4.7

Dolewikou, R. L., Sumekar, W., \& Setiadi, A. (2016). The profitability analysis of dairy cattle business on the group of dairy farmers in West Ungaran District Semarang Regency. J. Indonesian Trop. Anim. Agric, 4, 216-223. doi.org/10.14710/jitaa.41.4.216-223

Chander Y. D, B. D. Singh, S.Vishal, \& S. Subhasish. (2017). Effect of aloe vera (aloe barbadensis) supplementation on production indices, mortality and cost of production of broiler chicken. J. Anim. Rsc 7(1), 107-113.

Dwiloka, B., Setiadi, A., Santoso, S. I., Suprijatna, E., \& Susanti, S. (2015). Effects of duck feed supplemented with invasive giant salvinia (Salvinia molesta) on duck meat characteristics. Turkish Journal of Veterinary and Animal Sciences, 39(6), 668-675. doi.org/10.3906/vet-1411-52

Ibrahim, D., Abdelfattah-Hassan, A., Arisha, A. H., Abd El-Aziz, R. M., Sherief, W. R., Adil, S. H., ... \& Metwally, A. E. (2020). Impact of feeding anaerobically fermented feed supplemented with acidifiers on its quality and growth performance, intestinal villi and enteric pathogens of mulard ducks. Livestock Science, 242, 104299. doi.org/10.1016/j.livsci.2020.104299

Ibrahim, D., Moustafa, A., Shahin, S. E., Sherief, W. R., Abdallah, K., Farag, M. F., ... \& Ibrahim, S. M. (2021). Impact of Fermented or Enzymatically Fermented Dried Olive Pomace on Growth, Expression of Digestive Enzyme and Glucose Transporter Genes, Oxidative Stability of Frozen Meat and Economic Efficiency of Broiler Chickens. Frontiers in Veterinary Science, 8. doi.org 10.3389/fvets.2021.644325

Mukherjee, A. K., Kalita, P., Unni, B. G., Wann, S. B., Saikia, D., \& Mukhopadhyay, P. K. (2010). Fatty acid composition of four potential aquatic weeds and their possible use as fish-feed neutraceuticals. Food chemistry, 123(4), 1252-1254. doi.org/10.1016/j.foodchem.2010.05.057
Paguia, H. M., Paguia, R. Q., Balba, C., \& Flores, R. C. (2014). Utilization and evaluation of Moringa oleifera L. as poultry feeds. APCBEE procedia, 8, 343-347. doi.org/10.1016/j.apcbee.2014.03.051

Rathod, K. D., Mohale, D. D., Gadekar, S. D., \& Bidwe, K. U. (2019). Effect of different herbal feed additives on feed efficiency in broilers. Int. J. Veterinary Sci. Anim. Husb, 4, 24-26.

https://www.veterinarypaper.com/pdf/2019/vol4issu e4/PartA/4-4-10-233.pdf

Rawat, D., Shah, R., Nepali, D. B., \& Yadav, J. L. (2018). Effect of homeopathic medicine (alfalfa), methionine and lysine supplementation in low protein based diets on the performance of broiler chicken. International Journal of Applied Sciences and Biotechnology, 6(2), 174-180. doi.org/10.3126/ijasbt.v6i2.20432

Reyes, F. C. C., Aguirre, A. T. A., Agbisit Jr, E. M., Merca, F. E., Manulat, G. L., \& Angeles, A. A. (2018). Growth performances and carcass characteristics of broiler chickens fed akasya [Samanea Saman (Jacq.) Merr.] pod meal. Tropical Animal Science Journal, 41(1), 46-52. doi.org/10.5398/tasj.2018.41.1.46

Rutherford, A. (2001). Introducing ANOVA and ANCOVA : A GLM approach CA: Sage Publications, Thousand Oaks

Santoso, S. I., \& Setiadi, A. (2016). Profitable utilization of giant salvinia, Salvinia molesta, as local duck feed. International Journal of Poultry Science, 15(4), 121-125. doi.org/10.3923/ijps.2016.121.125

Santoso, S. I., Susanti, S., \& Setiadi, A. (2017). Economic analysis of male broiler chickens fed diets supplemented with Salvinia molesta. Int. J. Poult. Sci, 16, 233-237. doi.org/10.3923/ijps.2017.233.237

Sugiharto, S. (2019). A review of filamentous fungi in broiler production. Annals of Agricultural Sciences, 64(1), 1-8. doi.org/10.1016/j.aoas.2019.05.005

Sugiharto, S., \& Ranjitkar, S. (2019). Recent advances in fermented feeds towards improved broiler chicken performance, gastrointestinal tract micro ecology and immune responses: A review. Animal nutrition, 5(1), 1-10.

doi.org/10.1016/j.aninu.2018.11.001 